\title{
Characteristics and Potential Production of Frozen Semen of Pasundan Bull
}

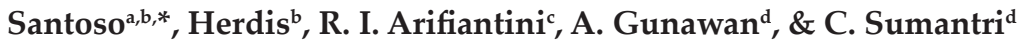 \\ aAnimal Production and Technology Study Program, Faculty of Animal Science, IPB University, \\ benter for Agricultural Production Technology, Agency for Assessment and Application of Technology, Jakarta, \\ Indonesia \\ 'Department of Veterinary Clinic, Reproduction, and Pathology, Faculty of Veterinary Medicine, IPB University, \\ ${ }^{\mathrm{d}}$ Department of Animal Production and Technology, Faculty of Animal Science, IPB University, \\ Kampus IPB Dramaga, Bogor 16680, Indonesia \\ *Corresponding author: santoso.drh@gmail.com \\ (Received 17-07-2020; Revised 29-09-2020; Accepted 19-10-2020)
}

\begin{abstract}
Pasundan cattle are one of the Indonesian domestic resources of animal-genetic materials that need to be developed and conserved. The aims of this study were to evaluate the characteristics of sperm and the potential production of frozen semen of Pasundan bulls. Ten Pasundan bulls were divided into two groups based on their fresh sperm motilities. Pasundan bulls were grouped based on their sperm motilities into group A (70-79\%) and group B (80-89\%). Secondary data were collected and confirmed with the primary data. The semen volume, $\mathrm{pH}$, color, consistency, mass movement, sperm concentration, motility, viability, membrane integrity, abnormality, and DNA integrity of fresh semen were evaluated. The semen was then diluted, frozen, and stored at $-196^{\circ} \mathrm{C}$. The results showed that the $\mathrm{pH}$ of the fresh semen in group $\mathrm{B}$ was lower $(\mathrm{p}<0.05)$ than group $\mathrm{A}$. Sperm concentration per ejaculate showed no difference with a range of $4312.36 \times 10^{6}$ to $6303.52 \times 10^{6}$. The viability and DNA integrity of fresh semen were not different between group A $(84.41 \pm 0.99 \%$; $91.19 \pm 0.79 \%)$ and group B $(86.35 \pm 2.16 \% ; 92.58 \pm 0.35 \%)$. DNA integrity of frozen semen of group B $(89.81 \pm 1.18 \%)$ was higher $(\mathrm{p}<0.05)$ than that of group $\mathrm{A}(86.83 \pm 0.60 \%)$. The sperm motility of frozen semen of group A $(<40 \%)$ was lower compared to SNI number 4869-1:2017. The frozen semen production of Pasundan bulls was between 144.18 to 191.29 straws/ejaculate. In conclusion, only bulls from fresh-semen sperm motility $80 \%-89 \%$ (group B) are eligible to be used as a semen source for artificial insemination.
\end{abstract}

Keywords: Pasundan cattle; characteristics of sperm; frozen semen

\section{INTRODUCTION}

Indonesia is a country that rich in genetic resources (GRs), including GRs for cattle. The Global Data Bank of Animal Genetic Resources states that cattle are categorized in a "risk" state of decline (FAO, 2015). Pasundan cattle is the result of the adaptation of more than 10 generations of crossing between Sundaicus/ Banteng/Bali cattle, Javanese, Ongole, and Madura cattle (Kementan, 2014). Pasundan cattle is a domestic breed having advantages in maintenance efficiency, resistance to drought, tropical diseases, and stress due to changes in the weather (Dwitresnadi et al., 2015). Legalization to protect the genetic resources of Pasundan cattle of Indonesian livestock was stipulated by Decree of the Minister of Agriculture No. 1051/Kpts/SR.120/10/2014 (Kementan, 2014).

A report from the West Java Central Statistics Agency in 2015 showed a decline in Pasundan cattle population from 50,000 heads in 2013 to 40,000 heads in 2015 (Dwitresnadi et al., 2015). On the other hand, increasing breeding and improving the genetic quality of cattle are required to maintain the population. Artificial Insemination (AI) using frozen semen is one of the efforts to increase the population and genetic quality of Pasundan cattle. Regulation of the Minister of Agriculture No. 10/Permentan/PK210/2016 requires that $60 \%$ of AI should be made from native and/or local breed (Kementan, 2016).

The selection of superior Pasundan bull is carried out through individual selection methods and pedigree. Bull selection is made by breeding soundness examination (BSE). A bull BSE includes the following three components; must be physically sound (includes scrotal circumference (SC)), have good sexual behavior, and be able to deliver good quality semen to the females they serve. Age of puberty and sexual maturity are the most important factors in BSE assessment due to their effects on the quality of semen (Barth, 2018). Semen analysis commonly included in BSE are sperm concentration, sperm motility, and sperm morphology (Stowe et al., 2013), as well as mass activity (Palmer, 2016).

The quality of frozen semen is determined to support the success of the AI program (Herbowo et al., 
2019). Sperm motility is an important factor in the quality of frozen semen. The capability of sperm to survive during the freezing process (freezing capability) is an important aspect to select the bull in AI center. Sperm motility decreases about $40 \%$ during freezing (Sorenson, 1979). One of the causes of damage to the head membrane of the sperm during storage is the presence of Reactive Oxygen Species (ROS) (Len et al., 2019). During the freezing process (cryopreservation), the viability of sperm will be reduced due to hyperosmotic diluents and temperature changes (Len et al., 2019; Indriastuti et al., 2020). Individual variation in frozen semen can affect sperm motility, viability, membrane integrity, abnormalities, and DNA fragmentation of frozen semen. Freezing capability is influenced by the individual aspect of animals (Indriastuti et al., 2020). Freezing capability and the characteristic of semen (macroscopic evaluation and sperm motility) has been investigated on the sperms of Pasundan bull. Sperms of Pasundan bull were able to recover after the freezing process by 59.62 $\pm 5.57 \%$ (Baharun et al., 2017).

Indonesian National Standardization (SNI) number 4869.1: 2017 requires the motility of fresh semen at least $70 \%$ and frozen semen at least $40 \%$ with a minimum of two individual movements (BSN, 2017). Spermatozoa motility and bull's capabilities to produce frozen semen are very important. Therefore, more comprehensive studies are required to evaluate the semen of Pasundan bull. This study was aimed to evaluate the characteristics of spermatozoa and the potential production for frozen semen of superior Pasundan bulls from two different spermatozoa motility groups.

\section{MATERIALS AND METHODS}

\section{Animals}

All procedures performed in this study were approved by the Animal Ethics Committee, Faculty of Veterinary Medicine, IPB University (Ethics Approval No: 161/KEH/SKE/VII/2019). A total of 10 Pasundan bulls aged 3-6 years with body weights (BW) range of $380-430 \mathrm{~kg}$ were used in this study. Fresh forage $(10 \%$ BW per head per day) and concentrate ( $1 \%$ BW per head per day) were given in the morning and evening. Drinking water was provided ad libitum. Moreover, Pasundan bulls with fresh-semen sperm motility $\geq$ 70\% (SNI number 4869-1: 2017) were divided into two groups. Group A (sperm motility $70-79 \%$ ) and group B (sperm motility $80 \%-89 \%$ ).

\section{Semen Collection and Evaluation}

Semen was collected twice a week every morning using an artificial vagina as a Standard Operating Procedures (SOP) of the Ciamis-West Java Regional Artificial Insemination Center (RAIC). Semen was taken to the laboratory for macroscopic and microscopic evaluations (Arifiantini, 2012). The macroscopic evaluation includes volume, color, consistency, and $\mathrm{pH}$. The microscopic evaluation includes mass movement, sperm motility, sperm concentration, sperm viability, and sperm abnormalities. Secondary data were obtained from laboratory records, and primary data were collected during the experimental period.

The mass motion was evaluated by dripping one drop of semen on the slide glass then observed under a microscope (Olympus CX 23, Japan) at 100x magnification. Sperm motility was evaluated at different stages; fresh semen and after being frozen and thawed using the Computer Assisted Semen Analyzer (CASA; Andro Vision, Minitub Germany). The characteristics of various motility movements were divided into total motility, progressive motility, progressive fast motility, progressive slow motility, circular motility, vibrating, and immotile. A total of $25 \mu \mathrm{L}$ semen was diluted with 725 $\mu \mathrm{L}$ of $0.9 \% \mathrm{NaCl}$, homogenized, and then dropped on a glass slide and cover with a cover glass. Observations were made under a microscope at 400x magnification. Sperm concentration (per $\mathrm{mL}$ ) was calculated using the Photometer SDM 6 (Minitub, Tiefenbach, Germany).

The viability of sperm was evaluated by mixing $20 \mu \mathrm{L}$ of semen and $80 \mu \mathrm{L}$ of eosin-nigrosin dyes (1:4) on the slide glass, then observed under a microscope at 400x magnification. Intact plasma membrane (IPM) was evaluated using the hypoosmotic swelling test (HOS Test) by mixing $20 \mu \mathrm{L}$ of semen in $1 \mathrm{~mL}$ of hypoosmotic medium $(0.3 \mathrm{~g}$ fructose and $0.7 \mathrm{~g}$ sodium Citrate into $100 \mathrm{~mL}$ distilled water then incubated in a water bath $\left(37^{\circ} \mathrm{C}\right)$ for 30 minutes (Arifiantini, 2012). Evaluation was carried out under a microscope with 400x magnification.

DNA integrity was tested by staining with Acridine Orange (AO) and observed using a fluorescence microscope (Yusrina et al., 2018). Fresh semen preparations were conducted by fixing with Carnoy solution of acetic acid and methanol (1:3). Observations were then made under a microscope with 400x magnification with an excitation light of $450-490 \mathrm{~nm}$ and a barrier filter of 530 $\mathrm{nm}$ in dark conditions.

\section{Estimation of Semen Production}

The number of motile sperms per ejaculate was calculated by multiplying the volume of semen by motility, and the concentration of sperm per ejaculate. The amount of frozen semen straw produced was calculated by dividing the number of motile sperm to the insemination dose $\left(25 \times 10^{6}\right.$ sperm in $0.25 \mathrm{~mL}$ or $100 \times 10^{6}$ sperm $\left.\mathrm{mL}^{-1}\right)$.

Semen was frozen using Tris Egg Yolk (TEY) extender with reference to the SOP of the AI center for the process of frozen-semen production. Semen was equilibrated in a cool top $\left(5^{\circ} \mathrm{C}\right)$ for four hours and then packed using the MPP Uno, automatic filling and sealing machine (Minitub, Tiefenbach, Germany). The freezing process was carried out in a liquid nitrogen vapor above using a $60 \times 40 \times 30 \mathrm{~cm}^{3}$ Styrofoam box for ten minutes. Frozen semen was then stored in a liquid nitrogen container $\left(-196^{\circ} \mathrm{C}\right)$ for further evaluation (sperm motility, viability, membrane integrity, and DNA integrity). 


\section{Statistical Analysis}

Data were analyzed using the student $\mathrm{T}$ test and were processed using SPSS version 26. Data were presented with the mean \pm standard error of the mean (SEM). P values less than 0.05 were considered statistically significant.

\section{RESULTS}

The results showed that the sperm motility of group A $(75.8 \pm 1.57 \%)$ was significantly lower than group B $(83.57 \pm 1.12 \%)$ (Table 2). These results were then used as the basis for grouping Pasundan bulls to determine the quality of semen, sperm motility characteristics, and potential production of frozen semen.

Macroscopic examination (Table 1) showed that the semen volume, consistency, and color were not different with a semen range of 5.14-8.20 mL. The color of the semen was milky white with medium consistency. The $\mathrm{pH}$ of the semen showed that group B (6.30) was lower $(\mathrm{p}<0.05)$ than that of group A (6.46). Microscopic characteristics of semen (Table 1) showed mass movements in both groups A and B, which were positive $2(++)$. Sperm concentration per $\mathrm{mL}\left(725.20 \times 10^{6} \mathrm{~mL}^{-1} ; 856.60 \times 10^{6} \mathrm{~mL}^{-1}\right)$ and sperm abnormalities $(9.41 \% ; 10.22 \%)$ in the 2 groups

Table 1. Characteristic of semen of Pasundan bulls in two different sperm motility groups

\begin{tabular}{lcc}
\hline \multirow{2}{*}{ Variables } & \multicolumn{2}{c}{ Sperm motility groups } \\
\cline { 2 - 3 } & $\mathrm{A}$ & $\mathrm{B}$ \\
\hline Number ejaculates & 80 & 80 \\
Volume ejaculate $(\mathrm{mL})$ & $8.20 \pm 1.32$ & $5.14 \pm 0.80$ \\
$\mathrm{pH}$ & $6.46 \pm 0.02^{\mathrm{a}}$ & Milk white \\
Color & Milk white & Medium \\
Consistency & Medium & $2.60 \pm 0.24$ \\
Mass movement & $2.60 \pm 0.24$ & $856.60 \pm 75.10$ \\
Sperm concentration $\left(10^{6} / \mathrm{mL}\right)$ & $725.20 \pm 107.65$ & $4312.36 \pm 667.39$ \\
Sperm concentration per ejaculate $\left(10^{6}\right)$ & $6303.52 \pm 1714.12$ & $10.22 \pm 0.66$ \\
Sperm abnormality $(\%)$ & $9.41 \pm 1.21$ & \\
\hline
\end{tabular}

Note: $\mathrm{A}=$ the sperm motility group of fresh semen $70 \%-79 \%$; $\mathrm{B}=$ the sperm motility group of fresh semen $80 \%-89 \%$. Means in the same row with different superscripts differ significantly $(\mathrm{p}<0.05)$.

Table 2. Characteristics of fresh semen and frozen semen of Pasundan bulls in two different sperm motility groups

\begin{tabular}{|c|c|c|}
\hline \multirow{2}{*}{ Variables } & \multicolumn{2}{|c|}{ Sperm motility groups } \\
\hline & A & $\mathrm{B}$ \\
\hline \multicolumn{3}{|l|}{ Fresh semen } \\
\hline Total motility (\%) & $91.12 \pm 0.76^{\mathrm{a}}$ & $94.76 \pm 0.94^{b}$ \\
\hline Progressive motility (\%) & $75.87 \pm 1.57^{\mathrm{a}}$ & $83.57 \pm 1.12^{b}$ \\
\hline Progressive fast motility (\%) & $25.74 \pm 3.11$ & $28.20 \pm 3.17$ \\
\hline Progressive slow motility (\%) & $30.95 \pm 5.52$ & $41.86 \pm 7.08$ \\
\hline Circular motility $(\%)$ & $19.18 \pm 3.53$ & $13.51 \pm 5.75$ \\
\hline Vibrating $(\%)$ & $15.25 \pm 0.96^{\mathrm{a}}$ & $11.19 \pm 1.17^{\mathrm{b}}$ \\
\hline Immotile $(\%)$ & $8.88 \pm 0.76^{\mathrm{a}}$ & $5.24 \pm 0.94^{\mathrm{b}}$ \\
\hline Sperm viability (\%) & $84.41 \pm 0.99$ & $86.35 \pm 2.16$ \\
\hline Sperm membrane integrity (\%) & $72.96 \pm 4.25$ & $79.07 \pm 2.52$ \\
\hline Sperm DNA integrity $(\%)$ & $91.19 \pm 0.79$ & $92.58 \pm 0.35$ \\
\hline \multicolumn{3}{|l|}{ Frozen semen } \\
\hline Total motility (\%) & $84.36 \pm 1.62$ & $87.41 \pm 2.65$ \\
\hline Progressive motility $(\%)$ & $32.93 \pm 4.06$ & $46.52 \pm 6.99$ \\
\hline Progressive fast motility (\%) & $9.67 \pm 7.50$ & $1.32 \pm 0.47$ \\
\hline Progressive slow motility (\%) & $21.62 \pm 9.31$ & $43.08 \pm 12.51$ \\
\hline Circular motility (\%) & $1.64 \pm 0.28$ & $2.12 \pm 1.02$ \\
\hline Vibrating (\%) & $51.43 \pm 3.21$ & $40.89 \pm 5.08$ \\
\hline Immotile (\%) & $15.64 \pm 1.62$ & $12.59 \pm 2.65$ \\
\hline Sperm viability (\%) & $43.13 \pm 5.92$ & $59.46 \pm 5.41$ \\
\hline Sperm membrane integrity (\%) & $51.27 \pm 2.44$ & $59.02 \pm 2.38$ \\
\hline Sperm DNA integrity (\%) & $86.83 \pm 0.60^{a}$ & $89.81 \pm 1.18^{\mathrm{b}}$ \\
\hline
\end{tabular}

Note: $A=$ the sperm motility group of fresh semen $70 \%-79 \%$; $B=$ the sperm motility group of fresh semen $80 \%-89 \%$. Means in the same row with different superscripts differ significantly $(p<0.05)$. 
were not different. Sperm concentrations per ejaculate in the two groups also showed no difference with a range of $4312.36 \times 10^{6}$ to $6303.52 \times 10^{6}$ of sperm.

The sperm motility after freezing was not different which were $32.93 \%$ and $46.52 \%$, respectively, in group A and B. Viability of sperm in fresh and frozen semen sperm showed the same value $(\mathrm{p}>0.05)$ between the two groups of bulls, $84.41 \%$ and $86.35 \%$, and $43.13 \%$ and $59.46 \%$. The IPM of fresh semen or after being frozen was also not different from the values of $72.96 \%$ to $79.07 \%$ and $51.27 \%$ to $59.02 \%$. Sperm with intact DNA (not fragmented) of fresh semen did not differ $(91.19 \%$ to $92.58 \%$ ) however, DNA integrity of frozen thawed in group B $(89.81 \%)$ were higher $(\mathrm{p}<0.05)$ than in group A (86.83\%) (Table 2).

The results showed that total motility, progressive motility, vibrating, and immotile fresh semen differ among groups A and B (Table 2). Total motility and progressive motility in group $B$ were higher $(p<0.05$; $94.76 \%$ and $83.57 \%$ ) than in group $\mathrm{A}$, whereas vibrating in group A was higher than in group B. Movement of sperm motility in semen freezing did not differ between groups.

The potential for frozen semen production per ejaculate did not different between groups A and B, with the potential for frozen semen production were 191.29 and 144.18 straws per ejaculate, respectively (Table 3 ).

\section{DISCUSSION}

Pasundan cattle as genetic resources of Indonesian domestic livestock have several advantages in the quality of semen as well as other native Indonesian cattle, such as Bali and Madura cattle. Semen consists of sperm and plasma in the ratio of $10 \%$ sperm and $90 \%$ plasma (Indriastuti et al., 2020). The average ejaculate volume in this study was higher compared to those reported by Baharun et al. (2017), i.e., $6.7 \mathrm{~mL}$ and $3.80 \mathrm{~mL}$, respectively. The ejaculate volume of Pasundan bulls was almost the same as the other native Indonesian cattle, such as Bali cattle, which is between $6.32 \mathrm{~mL}$ (Indriastuti et al., 2020) and $6.44 \mathrm{~mL}$ (Nabilla et al., 2018). The volume of ejaculate is also related to the libido which is influenced by testosterone (Herdis, 2017).

The color and consistency of Pasundan bull's semen were the same in two different groups. The color, consistency, mass movement, and concentration of sperm are interrelated parameters because the color of semen is determined by the density (concentration) of sperm and manifested in semen consistency and sperm mass movement. The same results were obtained in Sumba Ongole bull's semen which showed a moderate consistency with creamy in semen color (Maulana et al., 2019).

The $\mathrm{pH}$ of the semen in group B was lower (6.30). Semen from normal bull has $\mathrm{pH}$ range of 6.4 to 7.8 (Garner \& Hafez, 2000). Zhou et al. (2015) reported that the spermatozoa could be influenced directly by the $\mathrm{pH}$ of semen. Acidic environmental conditions had a greater influence than the alkaline environment on sperm viability. Therefore, decreasing the $\mathrm{pH}$ of bull semen increased viability and longevity (Contri et al., 2013). In
Table 3. Potential of frozen semen production on Pasundan bulls in two different sperm motility groups

\begin{tabular}{lcrc}
\hline \multirow{2}{*}{ Variables } & \multicolumn{2}{c}{ Sperm motility groups } \\
\cline { 2 - 4 } & \multicolumn{1}{c}{$\mathrm{A}$} & \multicolumn{1}{c}{$\mathrm{B}$} \\
\hline Total sperm motile $\left(10^{6}\right)$ & $4782.23 \pm 1283.01$ & $3604.41 \pm 560.96$ \\
$\begin{array}{l}\text { Straw production per } \\
\text { collection (pieces) }\end{array}$ & $191.29 \pm$ & 51.32 & $144.18 \pm 22.44$ \\
\hline
\end{tabular}

Note: $\mathrm{A}=$ the sperm motility group of fresh semen $70 \%-79 \%$; $\mathrm{B}=$ the motility group of fresh semen sperm $80 \%-89 \%$.

this study, the viability of fresh semen in group B was higher $(p>0.05)$ than in group A.

The $\mathrm{pH}$ level of semen also has implications for physiological conditions and some diseases. The characteristics of seminal plasma such as $\mathrm{pH}$, metabolic products, or free radicals can be changed by bacteria (Okazaki et al., 2010). Moreover, bacteria could also affect the function of sperm (Okazaki et al., 2010; Bussalleu et al., 2011). On the other hand, the presence of inflammatory cells and the results of bacterial metabolism affected the sperm environment, such as $\mathrm{pH}$ conditions (Sarkar et al., 2011). Therefore, the acidic environment, due to a pathological condition, can reduce sperm function (Contri et al., 2013).

Sperm concentration is the number of sperm cells per $\mathrm{mL}$ of semen. Sperm concentrations in this study per $\mathrm{mL}$ or per ejaculate were not different. Some bulls have a low volume but have a high concentration. On the other hand, some bulls have a high volume of semen but with a low concentration. The sperm concentration of Pasundan bulls was quite low compared with the normal range of sperm concentration of adult bull, which is 800 to $1200 \times 10^{6} \mathrm{~mL}^{-1}$ semen (Campbell et al. 2003). Sperm concentration of Pasundan bulls in this study was also lower than Bali bulls $\left(1164.81 \times 10^{6}\right.$ $\left.\mathrm{mL}^{-1}\right)$ (Indriastuti et al., 2020), SO bulls $\left(1256.42 \times 10^{6}\right.$ $\mathrm{mL}^{-1}$ ) (Maulana et al., 2019), PO bulls (1286.0x106 $\left.\mathrm{mL}^{-1}\right)$ (Ratnawati et al., 2018), Madura bulls (1076.0×106 $\left.\mathrm{mL}^{-1}\right)$ (Ratnawati et al., 2018), and Aceh bulls (1194.00x10 $\mathrm{mL}^{-}$ $\left.{ }^{1}\right)$ (Zulyazaini et al., 2016). The concentration of sperm in the bull semen is influenced by the testicle size and the frequency of semen collection. The scrotal circumference had a positive correlation with semen volume, sperm concentration, and motility in the Bali bulls (Saputra et al., 2017).

The viability of sperm in fresh semen of Pasundan bulls in this study was almost the same as reported by Baharun et al. (2017) (84.37\%). The viability of sperm in Bali bulls was $85.0 \%$ (Matahine et al., 2014), and in Madura bulls were $85.0 \%$ (Ratnawati et al., 2018). Moreover, the viability of sperm is also influenced by the breed of cattle. Some reports showed the sperm viability of Limousin and FH bulls were different (95.12\% VS 85\%) (Diliyana et al., 2014; Samik et al., 2014).

Plasma membrane integrity and sperm abnormalities of Pasundan bull in this study were not significantly different between groups. The integrity of the plasma membrane of the sperm after freezing decreased between $19.98 \%$ (B group) to $21.5 \%$ (A group). The result in this study was similar with the report of Casas \& 


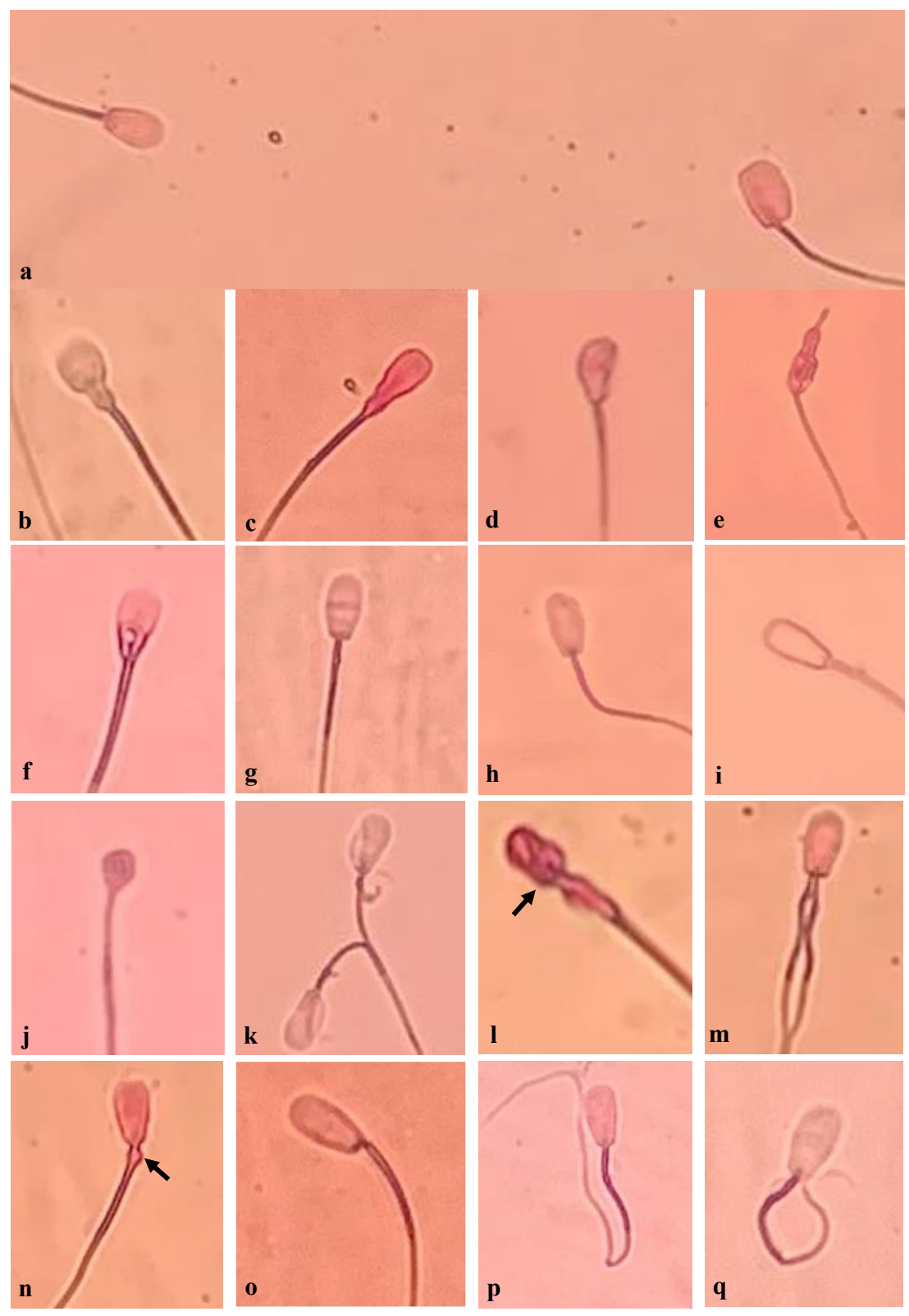

Figure 1. Sperm head morphology; normal and macrocephalus (a), pear shape (b), narrow at the base (c), abnormal contour (d), undeveloped (e), narrow (f), nuclear pouches $(\mathrm{g})$, knobbed acrosome $(\mathrm{h})$, flat acrosome (i), microcephalus (j), double head (k). Sperm tail morphology; defective midpiece (l), double tail $(\mathrm{m})$, accessory vestigial midpiece $(\mathrm{n})$, abaxial (o), coiled tails simple bent $(\mathrm{p})$, coiled tails double folded $(\mathrm{q})$.

Althouse (2009) that cooling and warming could damage the lipoproteins in the membrane of spermatozoa. The plasma membrane is responsible for regulating sodium, potassium, and calcium ions concentrations which are needed for mitochondrial activity and sperm motility (Pereira et al., 2017). Another study by Sukmawati et al. (2014) showed that motility occurs if sperm have a membrane that works well to produce energy.

The structure and function of mitochondria are affected by the morphological changes of the sperm mitochondria and midpiece defect (Figure 1-1,1-n) during cryopreservation (Agarwal et al., 2014; Meyers et al., 2019; Indriastuti et al., 2020). The structural changes that occurred in post-thawing spermatozoa cells related with cells adaptation to the change of energy sources. These changes reduced Adenosine Tri Phosphate (ATP) production by the mitochondria, which essential for sperm motility (Meyers et al., 2019). In addition, the changes also affected the cellular connectivity of sperm (Agarwal et al., 2014). Mitochondria changed its structure and decreased the function by $15 \%$ after freezing (Khalil et al., 2018). Mid piece defect affects metabolism in the mitochondria, which is responsible for the conversion of ATP and ADP for the sperm movement energy (Meyers et al., 2019).

DNA integrity is an indicator of sperm fertility (Ajina et al., 2017). Sperm DNA is packaged in prot- 
amine so that they can maintain the quality of DNA by protecting from Reactive Oxygen Species/ROS attacks (Gonzalez-Rojo et al., 2018). DNA damage can be caused by various factors such as heat stress, genetics, spermatogenesis, and inappropriate chromatin structure. In this study, DNA integrity after freezing was lower for both groups, $86.83 \%$ (group A) and $89.81 \%$ (group B), compared with fresh semen $91.19 \%$ (group A) and $92.58 \%$ (group B). An average decrease in intact DNA or DNA fragmentation across groups in this study was $3.56 \%$. The result indicated that DNA fragmentation of sperm in Pasundan bulls during cryopreservation was higher than that reported for Limousin, Ongole, Brahman, and Simmental bulls, which was around $1.84 \%$. However, DNA fragmentation of sperm in Pasundan bull observed in this study was lower than that reported by Priyanto et al. (2015) using the same breed of cattle and Sperm-Bos-Halomax ${ }^{\circledR}$ (Halotechdna, Spain) test which around $14.56 \%$. Another report showed the level of damage after freezing in Bali bulls using Sperm - Bos - Halomax $®$ was only 3.00\% (Indriastuti et al., 2020).

Sperm motility is one of the parameters that is often used to evaluate sperm fertility. The results showed a decrease in sperm motility after changes in temperature (Tabel 2). The extreme osmolality occurred during freezing will damage the composition of the lipid plasma membrane that eventually causes a decrease in sperm motility. Sperm motilities during post freezing in both groups were varying (Table 2). Semen storage at low temperatures resulted in structural damage to sperm due to cold shocks and the formation of ROS (Fattah et al., 2017). The study showed that the total motility (Table 2) of post thawing sperm in both groups was not significantly different.

Progressive motility consists of fast, slow, and circular motilities. Other sperm movements besides progressive are vibrating, and the rest is immotile. The result showed that progressive motility after thawing in group A sperm did not meet the standard of frozen semen criteria based on SNI number 4869-1: 2017 (BSN, 2017). The study also showed that the progressive motility of the sperm after thawing in Pasundan bulls was lower than in Bali bulls. Indriastuti et al. (2020) reported the progressive motilities of sperm after thawing in Bali bulls were between $64.69 \%$ and $71.23 \%$.

The potential for the production of frozen semen is the ability of bulls to produce frozen semen. The potential can be calculated in each ejaculate or production in one year with the assumption of 40 weeks of production or a total of 80 times with the assumption of twice a week semen collections (Ditjennak, 2018). The production of frozen semen produced by each individual bull depends on the number of motile sperm present in an ejaculate. The results of this study showed that there was a lot of frozen semen from bulls in group A that did not meet the standard, while frozen semen from group B, most of them meet the criteria of Indonesian National Standard of frozen semen. Results showed that the potential production of frozen semen from all groups was not different (Table 3).
The local breed of cattle at least, can produce 7,500 straws per year (Ditjennak, 2018). The potential production of frozen semen by Pasundan bull in this study was average 167 straws per ejaculate, which was equal to 13,400 straws for one year of 40 weeks. This amount was high enough for local breed bull, although it was seen that there are quite high individual variations with high standard error values. Another local breed cattle, i.e., Madura cattle, have the potential to produce frozen semen around 79 and to 99.14 straws per ejaculate or around 6,627 to 7,980 straws a year (Komariah et al., 2020; Aisah et al., 2017). In contrast, Bali cattle can produce frozen semen as many as 11,843.17 straws per year (Indriastuti et al., 2020). The potential for production of frozen semen is influenced by the volume and concentration of semen, having a positive correlation (Aisah et al., 2017).

\section{CONCLUSION}

Characteristics and potency of frozen semen of Pasundan bulls were not different between group A (the motility of fresh semen $70 \%-79 \%$ ) and group B (the motility of fresh semen $80 \%-89 \%$ ). However, the $\mathrm{pH}$ of the semen and DNA integrity of semen post thawing were different. The sperm motility after freezing of group A did not meet SNI's standard. The group B of Pasundan bulls in Ciamis RAIC eligible as sources of semen in order to maintain the genetic resources of local Indonesian cattle by increasing the population of Pasundan cattle through AI technology.

\section{CONFLICT OF INTEREST}

Asep Gunawan and Cece Sumantri serve as editors of the Tropical Animal Science Journal, but have no role in the decision to publish this article. Authors declare that there is no conflict of interest with any financial, personal, or other relationships with other people or organization related to the material discussed in the manuscript.

\section{ACKNOWLEDGEMENT}

The authors are grateful to Center for Agricultural Production Technology Agency for Assessment and Application of Technology, Faculty of Veterinary Medicine IPB University, and Ciamis Regional AI Center for supporting facilities.

\section{REFERENCES}

Aisah, S., N. Isnaini, \& S. Wahyuningsih. 2017. Quality of fresh semen and recovery rate of Bali cattle in different seasons. Indones. J. Anim. Sci. 27:63-79. https://doi.org/10.21776/ ub.jiip.2017.027.01.06

Ajina, T., 0. Ammar, Z. Haouas, A. Sallem, L. Ezzi, I. Grissa, W. Sakly, A. Jlali, \& M. Mehdi. 2017. Assessment of human sperm DNA integrity using two cytochemical tests: Acridine orange test and toluidine blue assay. Andrologia. 49:1-6. https://doi.org/10.1111/and.12765

Agarwal, A., G. Virk, C. Ong, S. S. Plessis. 2014. Effect of 
oxidative stress on male reproduction. World J. Mens. Health. 32:1-17. https://doi.org/10.5534/wjmh.2014.32.1.1

Arifiantini, R. I. 2012. Semen Collection and Evaluation Techniques in Animals. IPB Press, Bogor.

Baharun, A., R. I. Arifiantini, \& T. L. Yusuf. 2017. Freezing capability of Pasundan bull sperm using Tris-Egg Yolk TrisSoy and Andromed diluents. Indones. J. Vet. Sci. 11:45-49. https://doi.org/10.21157/j.ked.hewan.v11i1.5810

Barth, A. D. 2018. Review: The use of bull breeding soundness evaluation to identify subfertile and infertile bulls. Animal. 12:s158-s164. https://doi.org/10.1017/S1751731118000538

BSN (Badan Standardisasi Nasional). 2017. SNI Semen BekuBagian 1: Sapi. BSN, Jakarta

Bussalleu, E., M. Yesteb, L. Sepúlvedaa, E. Tornera, E. Pinarta, \& S. Bonet. 2011. Effects of different concentrations of enterotoxigenic and verotoxigenic E. coli on boar sperm quality. Anim. Reprod. Sci. 127:176-182. https://doi. org/10.1016/j.anireprosci.2011.07.018

Campbell, J.R., K.L. Campbell, \& M.D. Kenealy. 2003. Artificial Insemination: in Animal Sciences 4th ed. Mc Graw-Hill, New York.

Casas, I. \& G.C. Althouse. 2013. The protective effect of a $17^{\circ} \mathrm{C}$ holding time on boar sperm plasma membrane fluidity after exposure to $5^{\circ} \mathrm{C}$. Cryobiology 66: 69-75. https://doi. org/10.1016/j.cryobiol.2012.11.006

Contri, A., A. Gloriaa, D. Robbea, C. Valorzb, L. Wegherb, \& A. Carluccio. 2013. Kinematic study on the effect of $\mathrm{pH}$ on bull sperm function. Anim. Reprod. Sci. 136: 252-259. https://doi.org/10.1016/j.anireprosci.2012.11.008

Ditjennak (Direktorat Perbibitan dan Produksi Ternak). 2018. Roadmap Swasembada Pejantan Unggul 20182022. Directorate of Animal Breeding and Production, Directorate General of Animal Husbandry and Health, Ministry of Agriculture, Jakarta.

Diliyana, Y. F., T. Susilawati, \& S. Rahayu. 2014. Membrane intact of spermatozoa following sexing using percolldensity gradient centrifugation in Andromed and Caudal Epididymal Plasma-2 (CEP-2) added with 10\% egg yolk) extenders. J. Vet. 15:23-30. https://ojs.unud.ac.id/index. php/jvet/article/view/8781. [2 June 2020].

Dwitresnadi, R., M. Sulaiman, \& J. Arifin. 2015. Breeding activity performance of pasundan cattle on extensive system. J. Unpad. 4:1-11.

FAO (Food and Agriculture Organization of the United Nations). 2015. The Second Report on The State of The World's. Animal Genetics Resources for Food and Agriculture. Commision on Genetic Resources for Food and Agriculture, Food and Agriculture Organization of the United Nations, Rome.

Fattah, I., M. Sharafi, R. Masoudi, A Shahverdi, \& V. Esmaeili. 2017. L-Carnitine is a survival factor for chilled storage of rooster semen for a long time. Cryobiology 74:13-18. https://doi.org/10.1016/j.cryobiol.2016.12.011

Garner, D.L. \& E.S.E. Hafez. 2000. Spermatozoa and Seminal Plasma. In Hafez B. and Hafez, E.S.E. Reproduction in Farm Animals. $7^{\text {th }}$ ed. Lippincott Williams and Wilkins, Philadelphia.

Gonzalez-Rojo, S., C. Fernandez-Diez, M. Lombo, \& M.P. Herraez. 2018. Distribution of DNA damage in the sperm nucleus: a study zebrafish as a model of histone-packaged chromatin. Theriogenology 122:109-115. https://doi. org/10.1016/j.theriogenology.2018.08.017.

Herbowo M.T., R.I. Arifiantini, N.W.K. Karja, \& R.G. Sianturi. 2019. Cryopreservation of swamp buffalo semen in skim milk yolk-based diluent with two different cryoprotectants. Trop. Anim. Sci. J. 42:13-18. https://doi.org/10.5398/ tasj.2019.42.1.13

Herdis. 2017. Fresh semen characteristic of Garut rams fighting type at three semen collection time. Zoologi 2:172 - 183.
Indriastuti, R., M.F. Ulum, R.I. Arifiantini, \& B. Purwantara. 2020. Individual variation in fresh and frozen semen of Bali bulls (Bos sondaicus). Vet. World. 13: 840-846. https:// doi.org/10.14202/vetworld.2020.840-846

Kementan (Kementerian Pertanian). 2014. Decree of the Minister of Agriculture No. 1051/Kpts/SR.120/10/2014 Concerning the Determination of Pasundan Cattle Clumps. Ministry of Agriculture, Jakarta.

Kementan (Kementerian Pertanian). 2016. Regulation of the Minister of Agriculture of the Republic of Indonesia Number 10/Permentan/PK.210/3/2016 concerning the Supply and Distribution of Ruminant Animal Frozen Semen. Ministry of Agriculture, Jakarta.

Khalil, W. A., M. A. El-harairy, A. B. Zeidan, \& M.A.E. Hassan. 2018. Evaluation of bull during and after cryopreservation: Structural and ultrastructural insights. Int. J. Vet. Sci. \& Med. 6: S49-S56. https://doi.org/10.1016/j.ijvsm.2017.11.001

Komariah, R.I. Arifiantini, M. Aun, \& E. Sukmawati. 2020. The quality of fresh semen and frozen semen production Madura bulls in different seasons. J. Anim. Prod. Proces. Tech. 8:15-21. https://doi.org/10.29244/jipthp.8.1.15-21

Len, J. S., W. S. D. Koh \& S. X. Tan. 2019. The roles of reactive oxygen species and antioxidants in cryopreservation. Bioscience Reports. 39:BSR20191601. https://doi. org/10.1042/BSR20191601

Matahine, T., Burhanuddin, \& A. Marawali. 2014. The effectiveness of palmyra juice in maintaining motility,viability and longevity of Bali cattle sperm. J. Vet. 15:263-273. https://ojs.unud.ac.id/index.php/jvet/article/view/9719. [4 June 2020].

Maulana, T., S. Said, R.I. Arifiantini, \& M.A. Setiadi. 2019. Sex sorting sperm of Sumba Ongole bulls by using snakehead fish (Channa striata) albumin extract. J. Indones. Trop. Anim. Agricul. 44:106-113. https://doi.org/10.14710/ jitaa.44.1.106-113

Meyers, S., E. Bulkeley, \& A. Foutouhi. 2019. Sperm mitochondrial regulation in motility and fertility in horses. Reprod. Dom. Anim. 54:22-28 https://doi.org/10.1111/rda.13461

Nabilla, A., R. I. Arifiantini, \& B. Purwantara. 2018. Fresh semen quality of Bali bull in productiveand non-productive ages and determinationof cryoprotectant concentration in Tris Egg Yolk extender. J. Vet. 19:242-250. https://doi. org/10.19087/jveteriner.2018.19.2.242

Okazaki, T., T. Miharaa, Y. Fujitaa, S. Yoshidab, H. Teshimab, \& M. Shimada. 2010. Polymyxin B neutralizes bacteria-released endotoxin and improves the quality of boar sperm during liquid storage and cryopreservation. Theriogenology 74:1691-1700. https://doi.org/10.1016/j.theriogenology.2010.05.019

Palmer, C.W., Y. Persson, \& L. Söderquist. 2013. Classification of the potential breeding ability of range beef bulls based on semen quality parameters in samples collected by transrectal massage-A comparison of the Swedish and Canadian systems. Anim. Reprod. Sci. 140:124-130. https:// doi.org/10.1016/j.anireprosci.2013.06.001

Palmer, C.W. 2016. Management and breeding soundness of mature bulls. Vet. Clin. Food Anim. 32: 479-495. https:// doi.org/10.1016/j.cvfa.2016.01.014

Pereira, R., R. Sá, A. Barros, \& M. Sousa. 2017. Major regulatory mechanisms involved in sperm motility. Asian J. of Andro. 19:5-14. http://www.ajandrology.com/text. asp?2017/19/1/5/167716. [2 June 2020].

Priyanto, L., R.I. Arifiantini, \& T.L. Yusuf. 2015. Detection of sperm DNA damage infresh and frozen semen using Toluidine Blue staining. J. Vet. 16:48-55. https://ojs.unud. ac.id/index.php/jvet/article/view/13318. [2 June 2020].

Ratnawati, D., N. Isnaini, \& T. Susilawati. 2018. Character motility of liquid semen on Ongole crossbreed (PO), Bali and Madura bulls with different diluents at cold storage. Asian 
J. Microbiol. Biotech. Env. Sci. 20:21-28.

Samik, A., Y. Oktanella, T. Hernawati, N.M.R. Widjaja, \& I.P.P. Dewanti. 2014. Additional osteopontin into frozen friesian-holsteinsemen diluter increases the expression of B-cell CII/Lymphoma-2 in post thawing sperm. J. Vet. 15: 461-466. https://ojs.unud.ac.id/index.php/jvet/article/ view/13224. [4 June 2020].

Saputra, D.J., M. N. Ihsan \& N. Isnaini. 2017. Correlation between the scrotum circle with cement volume, concentration and motility of Bali beef spermatozoa. J. Trop. Anim. Prod. 18:59-68. https://doi.org/10.21776/ ub.jtapro.2017.018.02.9

Sarkar, O., J. Bahrainwala, S. Chandrasekaran, S. Kothari, P.P. Mathur, \& A. Agarwal. 2011. Impact of inflammation on male fertility. Bioscience (Elite Ed) 1:89-95. https://doi. org/10.2741/e223

Sorenson, Jr. A.M. 1979. Laboratory Manual for Animal Reproduction. 4th ed. American Press, Boston.

Stowe, H.M., M. Miller, M.G. Burns, S.M. Calcatera, J.G. Andrae, G.E. Aiken, F.N. Sehriek, T. Cushing, W.C. Bridges, \& S.L. Pratt. 2013. Effects of fescue toxicosis on bull growth, semen characteristics, and breeding soundness evaluation. J. Anim. Sci. 91:3686-3692. https://doi. org/10.2527/jas.2012-6078

Sukmawati, E., R.I. Arifiantini, \& B. Purwantara. 2014. Freezing capacity of sperm on various type of superior bulls. JITV. 1:168-175. https://doi.org/10.14334/jitv.v19i3.1079

Yusrina, A., N. Solihati, \& N. Hilmia. 2018. Effect of globalhione-based sperm sexing processes on motility and whole chilled plasma membrane local sheep semen. J. Anim. Sci. Padjajaran Univ. 18:40-45. https://doi.org/10.24198/jit. v18i1.17307

Zhou, J., L. Chen, J. Li, H. Li, Z. Hong, M. Xie, S. Chen, B. Yao. 2015. The semen $\mathrm{pH}$ affects sperm motility and capacitation. PLoS ONE. 10:e0132974. https://doi.org/10.1371/journal.pone.0132974

Zulyazaini, S., Dasrul, M.A. Wahyuni, \& M.A.N. Abdullah. 2016. The characteristics of semen and chemical composition of the seminal plasma of Aceh cattle maintained in BIBD Saree Aceh Besar. Agripet. 16:121-130. https://doi. org/10.17969/agripet.v16i2.5803 